\title{
Concentrations of 17 elements in muscle, gills, liver and gonads of five economically important fish species from the Danube River
}

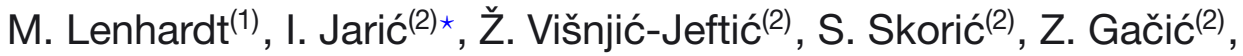 \\ M. Pucar ${ }^{(2)}, A$. Hegediš $(2)$
}

Received October 19, 2012

Revised November 30, 2012

Accepted December 7, 2012

\section{ABSTRACT}

Key-words: heavy metal, carp, catfish, Danube, pollution
The Danube River in the vicinity of the city of Belgrade receives large amounts of untreated or poorly treated communal and industrial waste waters. The aim of this study was to assess elemental accumulation patterns in a number of economically important fish species in this area that belong to different trophic levels. Concentrations of 17 elements (Al, As, B, $\mathrm{Ba}, \mathrm{Cd}, \mathrm{Co}, \mathrm{Cr}, \mathrm{Cu}, \mathrm{Fe}, \mathrm{Li}, \mathrm{Mn}, \mathrm{Mo}, \mathrm{Ni}, \mathrm{Pb}, \mathrm{Se}, \mathrm{Sr}$ and $\mathrm{Zn}$ ) were assessed in liver, muscle, gills and gonads of silver carp (Hypophthalmichthys molitrix), freshwater bream (Abramis brama), white bream (Blicca bjoerkna), common carp (Cyprinus carpio) and wels catfish (Silurus glanis) from the Danube River in Serbia by the use of ICP-OES. Silver carp specimens were differentiated from the other four species by high concentrations of $\mathrm{Al}$ and $\mathrm{Fe}$ in the liver. Common carp specimens were differentiated by high concentrations of $\mathrm{Zn}$ in gills, muscle and liver. Distribution of elements among different tissues had a consistent pattern among the species. Concentrations of $\mathrm{Pb}, \mathrm{Cd}, \mathrm{As}, \mathrm{Zn}, \mathrm{Cu}$ and $\mathrm{Fe}$ in muscle were at acceptable levels for human consumption, while concentrations of Fe and $\mathrm{Zn}$ were above maximum acceptable concentrations in liver and gonads.

\section{RÉSUMÉ}

Les concentrations de 17 éléments dans le muscle, le foie, les branchies et les gonades de cinq espèces de poissons économiquement importants du Danube

Mots-clés : métaux lourds, carpes, silure, Danube, pollution
Le Danube à proximité de la ville de Belgrade reçoit de grandes quantités d'eaux usées communales et industrielles non traitées ou mal traitées. Le but de cette étude était d'évaluer les schémas d'accumulation des éléments dans un certain nombre d'espèces de poissons économiquement importants dans cette région, qui appartiennent à différents niveaux trophiques. Les concentrations de 17 éléments (Al, As, B, Ba, Cd, Co, Cr, Cu, Fe, Li, Mn, Mo, Ni, Pb, Se, Sr et Zn) ont été évaluées dans le foie, le muscle, les branchies et les gonades de la carpe argentée (Hypophthalmichthys molitrix), la brème commune (Abramis brama), la brème bordelière (Blicca björkna), la carpe commune (Cyprinus carpio) et silure glane (Silurus glanis) du Danube en Serbie par l'utilisation de I'ICP-OES. Les spécimens de carpes argentées se différencient des quatre autres espèces par des concentrations élevées d'aluminium et de fer dans le foie. Les spécimens de carpes communes sont caractérisés par de fortes concentrations de Zn dans les branchies, les muscles et le foie. La répartition des éléments entre différents tissus a un schéma

(1) Institute for Biological Research, University of Belgrade, Despota Stefana 142, 11000 Belgrade, Serbia

(2) Institute for Multidisciplinary Research, University of Belgrade, Kneza Viseslava 1, 11000 Belgrade, Serbia

* Corresponding author: ijaric@imsi.rs 
semblable entre les espèces. Les concentrations de $\mathrm{Pb}, \mathrm{Cd}, \mathrm{As}, \mathrm{Zn}, \mathrm{Cu}$ et Fe dans les muscles étaient à des niveaux acceptables pour la consommation humaine, tandis que les concentrations de Fe et $\mathrm{Zn}$ étaient au-dessus des concentrations maximales acceptables dans le foie et les gonades.

\section{INTRODUCTION}

Many industrial facilities along the Danube River in Serbia release untreated waste water into the river (Teodorović et al., 2000; Stanković, 2006). Combined with the release of untreated communal waste waters, this makes Serbia one of the major pollution emitters in the Danube Basin (Kirschner et al., 2009). Heavy metals are considered to be among major pollutants in the Danube in Serbia (Teodorović, 2009), which is especially pronounced in the Danube River section between the two largest cities in Serbia, Novi Sad and Belgrade.

Fishery has a long tradition in Serbia. In 2010, there were 511 registered commercial fishermen on the Danube in Serbia, with the annual catch of approximately $3000 \mathrm{t}$ (Smederevac-Lalić et al., 2011). The major problem with regard to the commercial fishery in this area is a lack of organized purchase of the catch, as well as the distribution of fish directly to consumers, without any prior detailed analysis. Regular analysis of the fish meat quality is considered as a very important measure. Through the food chain, fish are able to accumulate pollutants such as heavy metals at levels that could represent a potential risk, not only to the fish but also to piscivorous animals and the human population (Berveots and Blust, 2003; Burger and Gochfeld, 2005; Çalta and Canpolat, 2006; Alibabić et al., 2007; Yilmaz et al., 2007). Heavy metals and trace elements differ in their accumulation levels and patterns depending on fish species, as well as on a fish tissue (Rashed, 2001; Višnjić-Jeftić et al., 2010; Jarić et al., 2011). Special attention should be given to tissues that are used by humans (i.e., muscle, liver and gonads) and to fish species that are able to accumulate higher concentrations of toxic elements. Certain trace elements are essential in small amounts for the body growth and development (i.e., $\mathrm{Co}, \mathrm{Cr}, \mathrm{Cu}, \mathrm{Mn}, \mathrm{Mo}$ and $\mathrm{Zn}$ ), while the excessive elemental concentrations are toxic and even potentially carcinogenic to humans (Agah et al., 2009).

In the present study, 17 elements were analyzed in muscle, gills, liver and gonads of the five commercially exploited fish species from the Danube River, caught in the vicinity of the city of Belgrade. The species were selected as those most common in the Danube fishermen catch in Serbia. The main goal was to compare accumulation patterns among different fish tissues and species, as well as to determine whether specific elements exceeded maximum acceptable concentrations for human consumption.

\section{MATERIAL AND METHODS}

\section{> STUDY AREA AND SAMPLE COLLECTION}

Fish specimens were collected from the Danube River section situated within the city of Belgrade (1173 km of the river flow). Samples were collected during February-May 2010, and comprised five commercially exploited fish species: silver carp (Hypophthalmichthys molitrix Valenciennes 1844, $N=11$ ), freshwater bream (Abramis brama Linnaeus 1758, $N=11$ ), white bream (Blicca bjoerkna Linnaeus 1758, $N=12$ ), common carp (Cyprinus carpio Linnaeus $1758, N=6$ ) and wels catfish (Silurus glanis Linnaeus $1758, N=8$ ). The species were selected as those that are regular in fishermen catch in the study area. Common carp and wels catfish are among the economically most valuable fish species in the Danube in Serbia, as well as silver carp, although it is a non-native species (Lenhardt et al., 2011). These five fish species occupy different habitats and differ with regard to their diet. White bream is a demersal species, while the other four species are benthopelagic. With the exception of wels catfish, 
which is a non-migratory species, the other species are potamodromous. The main food of silver carp (in specimens larger than $1.5 \mathrm{~cm}$ standard length) is phytoplankton. Freshwater bream mainly feeds on insects (particularly on chironomids), small crustaceans, mollusks and plants, while white bream feeds on different benthic invertebrates. Common carp is an omnivorous species, while adult wels catfish preys on fish and other aquatic vertebrates.

Specimens were sacrificed with a quick blow to the head, measured for their total weight (g) and total body length $(\mathrm{cm})$, and subsequently dissected. Samples were removed from gills, liver, gonads and the right dorsal muscle, washed with distilled water and stored on $-20^{\circ} \mathrm{C}$ prior to analysis. Gonad samples were obtained only from freshwater bream, white bream and common carp specimens, since they were still undeveloped in the remaining two species.

\section{$>$ ANALYTICAL PROCEDURES}

Samples were dried by Freeze Dryers Rotational-Vacuum-Concentrator, GAMMA 1-16 LSC, Germany, and subsequently processed in a microwave digester (speedwave ${ }^{\mathrm{TM}} \mathrm{MWS}^{-3^{+}}$; Bergof Products + Instruments $\mathrm{GmbH}$, Eningem, Germany), using 0.2-0.5 g dry weight sample portions and $6 \mathrm{~mL}$ of $65 \% \mathrm{HNO}_{3}$ and $4 \mathrm{~mL}$ of $30 \% \mathrm{H}_{2} \mathrm{O}_{2}$ (Merck suprapure) at a food temperature program $\left(100-170^{\circ} \mathrm{C}\right)$. A number of blank samples were also prepared, to resolve potential presence of trace elements in utilized chemicals. Digested samples were cooled to a room temperature and diluted with distilled water to a total volume of $25 \mathrm{~mL}$. The analysis was performed by inductively-coupled plasma optical spectrometry (ICP-OES). It included the assessment of concentrations of the following 17 elements: Al, As, B, Ba, Cd, $\mathrm{Co}, \mathrm{Cr}, \mathrm{Cu}, \mathrm{Fe}, \mathrm{Li}, \mathrm{Mn}, \mathrm{Mo}, \mathrm{Ni}, \mathrm{Pb}, \mathrm{Se}, \mathrm{Sr}$ and $\mathrm{Zn}$. The following wavelength lines of the ICPOES analysis were used (nm): Al 394.401, As 189.042, B 249.773, Ba 233.527, Cd 228.802, Co 228.616, Cr 205.552, Cu 324.754, Fe 259.941, Li 460.289, Mn 259.373, Mo 202.095, Ni 231.604, Pb 220.353, Se 196.090, Sr 460.733, and Zn 206.191. The analytical process quality control, performed by the use of BCR-185R reference material of bovine liver and IAEA-336 Lichen reference material, indicated that the resulting concentrations were within $90-115 \%$ of the certified values for all measured elements. There were no certified values for $\mathrm{B}$ and $\mathrm{Li}$. All concentrations were expressed as $\mu \mathrm{g} \cdot \mathrm{g}^{-1}$ dry weight $(\mathrm{dw})$.

\section{> STATISTICAL ANALYSIS}

Statistical analysis included comparisons of elemental concentrations among the five fish species, as well as among different tissues within each species. Assessment of the differences among the groups was performed by means of the Jonckheere-Terpstra test. Relationships between the fish size and weight and trace element levels in different tissues were assessed by the Spearman's non-parametric correlation test. Principal component analysis (PCA) was applied to assess the differentiation among the analyzed fish tissues and among the five analyzed species, based on elemental concentrations. The untreated data for elemental concentrations in each tissue were used as input variables. Concentrations in muscles were also recalculated to the wet tissue weight and compared with the maximum acceptable concentrations (MAC) in fish meat for the utilization in human diet, established by the European Union (EU; European Commission Regulation, 2006), Food and Agriculture Organization of the United Nations (FAO; FAO, 1983) and the national legislation (Baltić and Teodorović, 1997).

\section{RESULTS}

The average weight, total body length and elemental concentrations in four analyzed tissues of each of the studied species are presented in Table I. The analysis has revealed that concentrations of $\mathrm{Cd}$, $\mathrm{Co}$ and $\mathrm{Pb}$ were below detection thresholds in all analyzed samples. Concentrations of $\mathrm{Cr}$, $\mathrm{Li}$ and $\mathrm{Ni}$ were each above detection thresholds in only a single liver sample 
of silver carp (21.369, 9.821 and $0.813 \mu \mathrm{g} \cdot \mathrm{g}^{-1} \mathrm{dw}$, respectively), while Se was present only in a single freshwater bream liver sample $\left(1.641 \mu \mathrm{g} \cdot \mathrm{g}^{-1} \mathrm{dw}\right)$. Consequently, concentrations of these elements were not subjected to statistical analysis.

Comparisons among the five analyzed fish species showed that they significantly differed in a number of the assessed elements $(p<0.05$; Table I). The largest number of differences in element levels was observed in wels catfish, and this species also had on the average the largest number of minimum elemental concentrations. Significant differences were also numerous between common carp and the other four species. In gills, most of the analyzed elements had the lowest concentrations in wels catfish. The greatest similarity was observed between the freshwater bream and white bream, since there was the smallest number of significant differences between these two species.

PCA indicated that the silver carp samples were grouped based on increased concentrations of Mo, Mn and Sr in gills, while the wels catfish gills were characterized by the lowest concentrations of the analyzed elements (Figure 1). PCA conducted on liver samples indicated that the silver carp was grouped based on increased Mo and $\mathrm{Cu}$ concentrations (Figure 2), while the other four species substantially overlapped. As and Cu were excluded from PCA, since As was below detection thresholds in all gill samples, and $\mathrm{Cu}$ was registered only in a single gill sample (in wels catfish, $160.11 \mu \mathrm{g} \cdot \mathrm{g}^{-1} \mathrm{dw}$ ).

Elemental distribution among different tissues had a consistent pattern among the species. Concentrations of $\mathrm{As}, \mathrm{Cu}$ and $\mathrm{Mo}$ were highest in liver, $\mathrm{Al}, \mathrm{B}, \mathrm{Ba}, \mathrm{Mn}$ and $\mathrm{Sr}$ in gills, while Fe and $\mathrm{Zn}$ had the highest concentrations in both liver and gills. The lowest concentrations of the most of the analyzed elements were observed in muscle, followed by gonads. Overall, gills were most differentiated tissue based on the level of elemental accumulation.

There were only a few significant correlations between the elemental accumulation and fish size and weight. In the liver of silver carp, Al had a strong positive correlation with the fish weight and total and standard length (correlation coeff. $0.718,0.782$ and 0.809 , respectively, $p<0.05$ ). Mo had a weak but significant negative correlation with fish size and weight in gills and liver of silver carp (correlation coeff. ranged between -0.624 and $-0.764, p<0.05$ ), in gills of freshwater bream (correlation coeff. ranged between -0.704 and $-0.746, p<0.05$ ) as well as with fish standard length in gonads of common carp (correlation coeff. $-0.900, p<0.05$ ). In gills of wels catfish, $\mathrm{Sr}$ was negatively correlated with fish length and weight (correlation coeff. ranged between -0.743 and $-0.814, p<0.05$ ).

Concentrations of $\mathrm{Pb}, \mathrm{Cd}, \mathrm{As}, \mathrm{Zn}, \mathrm{Cu}$ and Fe were below both national and EU MAC in all analyzed muscle samples of analyzed fish species. However, comparison of the prescribed MAC with the concentrations in other tissues, which are sometimes also utilized in human diet, indicated that national MAC for Fe (for canned fish meat, $30.0 \mu \mathrm{g} \cdot \mathrm{g}^{-1}$ wet weight) was exceeded in liver of all analyzed species. Fe concentrations ranged among different species from 36.24 to $146.52 \mu \mathrm{g} \cdot \mathrm{g}^{-1}$ wet weight in liver. The maximum concentrations were observed in the liver of common carp, wels catfish and silver carp (mean concentrations 130.91, 131.30 and $146.52 \mu \mathrm{g} \cdot \mathrm{g}^{-1}$ wet weight, respectively). Furthermore, both national and FAO MAC for $\mathrm{Zn}$ (30.0 $\mu \mathrm{g} \cdot \mathrm{g}^{-1}$ wet weight) were exceeded in silver carp and common carp liver (mean concentrations 45.77 and $183.84 \mu \mathrm{g} \cdot \mathrm{g}^{-1}$ wet weight, respectively), as well as in freshwater bream and white bream gonads (45.84 and $37.71 \mu \mathrm{g} \cdot \mathrm{g}^{-1}$ wet weight, respectively). Finally, both national and FAO MAC for $\mathrm{Cu}\left(30.0 \mu \mathrm{g} \cdot \mathrm{g}^{-1}\right.$ wet weight) were slightly exceeded in silver carp liver (mean concentration $39.15 \mu \mathrm{g} \cdot \mathrm{g}^{-1}$ wet weight).

\section{DISCUSSION}

Analysis performed in this study revealed the existence of differences in concentrations of the assessed elements among species, as well as among the assessed tissues. Concentrations of $\mathrm{Pb}, \mathrm{Cd}, \mathrm{As}, \mathrm{Zn}, \mathrm{Cu}$ and $\mathrm{Fe}$ were below MAC in all analyzed muscle samples, which indicates that the meat of studied species should be safe for utilization in human diet. However, concentrations in other tissues (liver and gonads) exceeded MAC, which is in line with previous studies on fish from Danube (Jarić et al., 2011). Such tissues should be therefore omitted 
M. Lenhardt et al.: Knowl. Managt. Aquatic Ecosyst. (2012) 407, 02

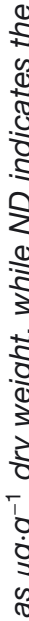

\begin{tabular}{|c|c|c|}
\hline & 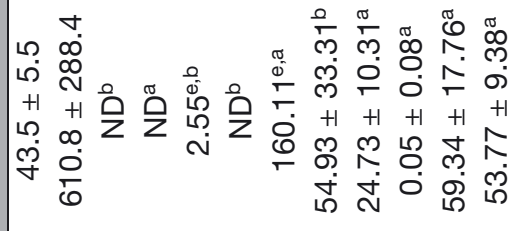 & 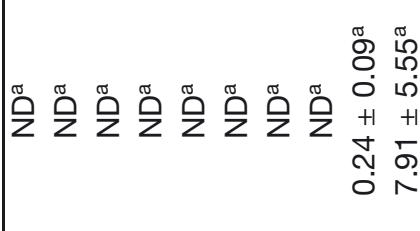 \\
\hline & 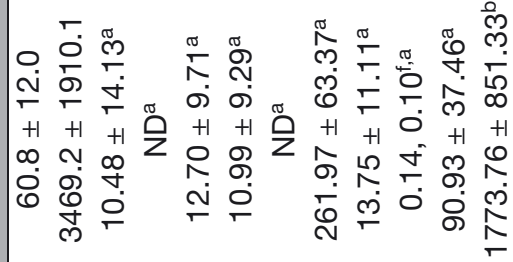 & 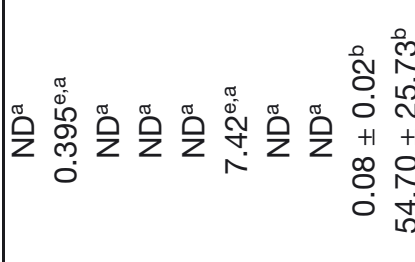 \\
\hline & 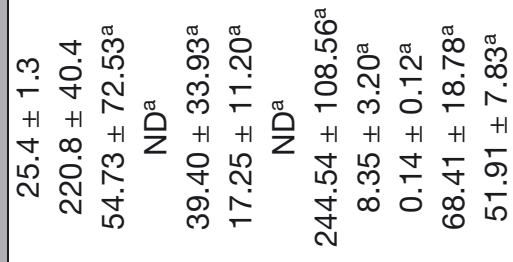 & \\
\hline & 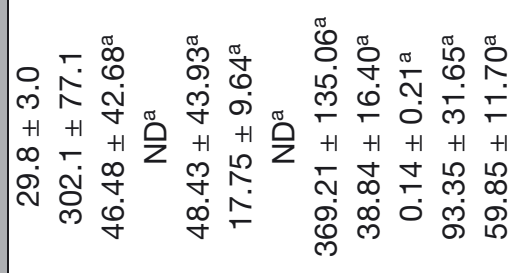 & \\
\hline & 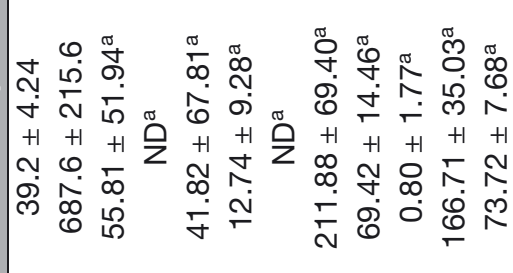 & 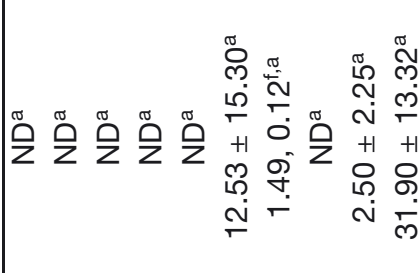 \\
\hline & 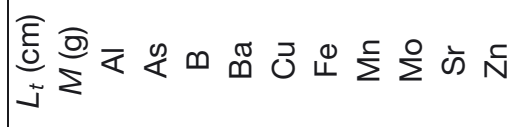 & 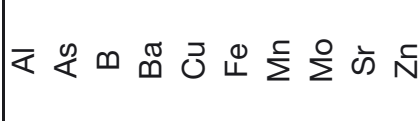 \\
\hline & 0 & $\Sigma$ \\
\hline
\end{tabular}

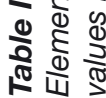




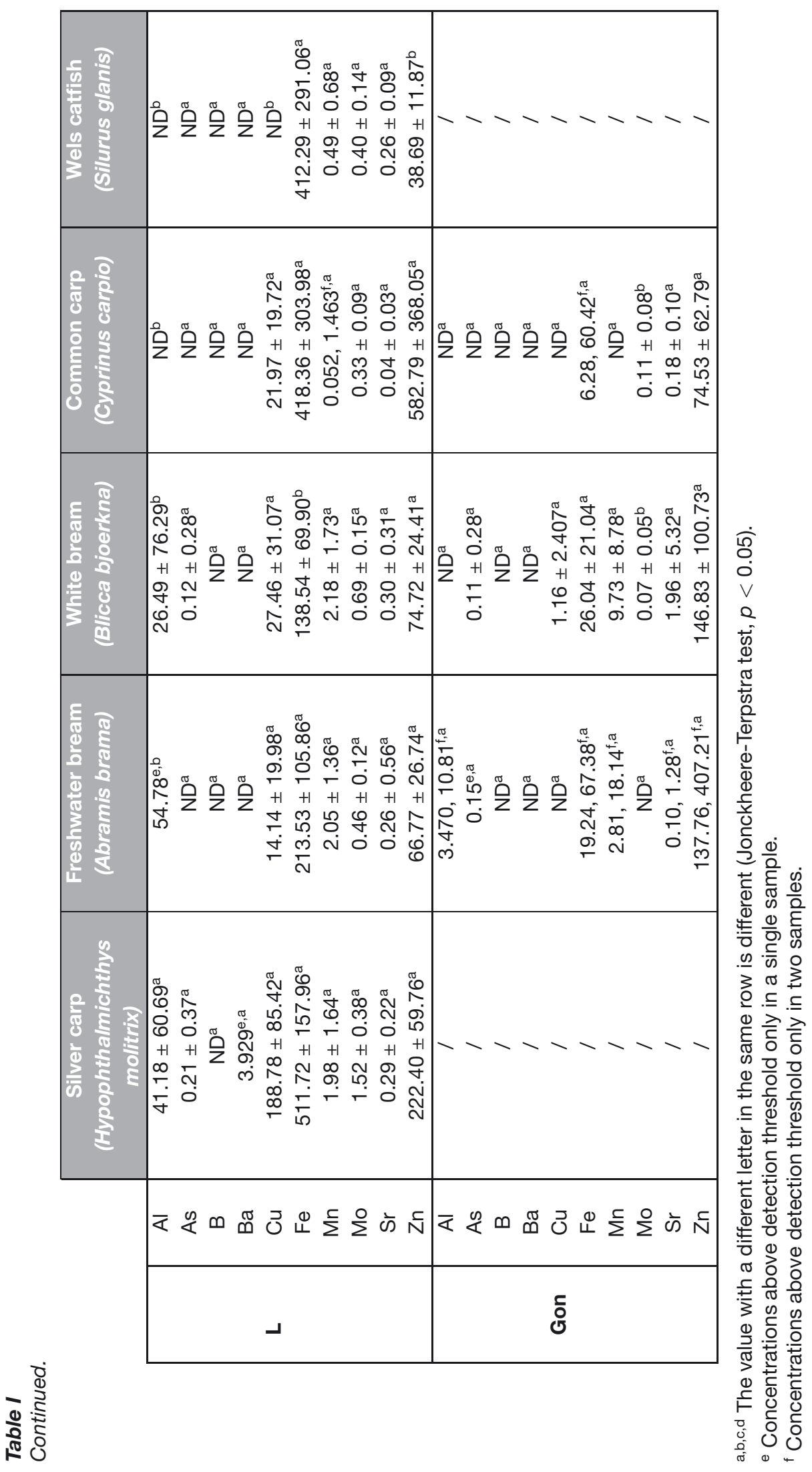




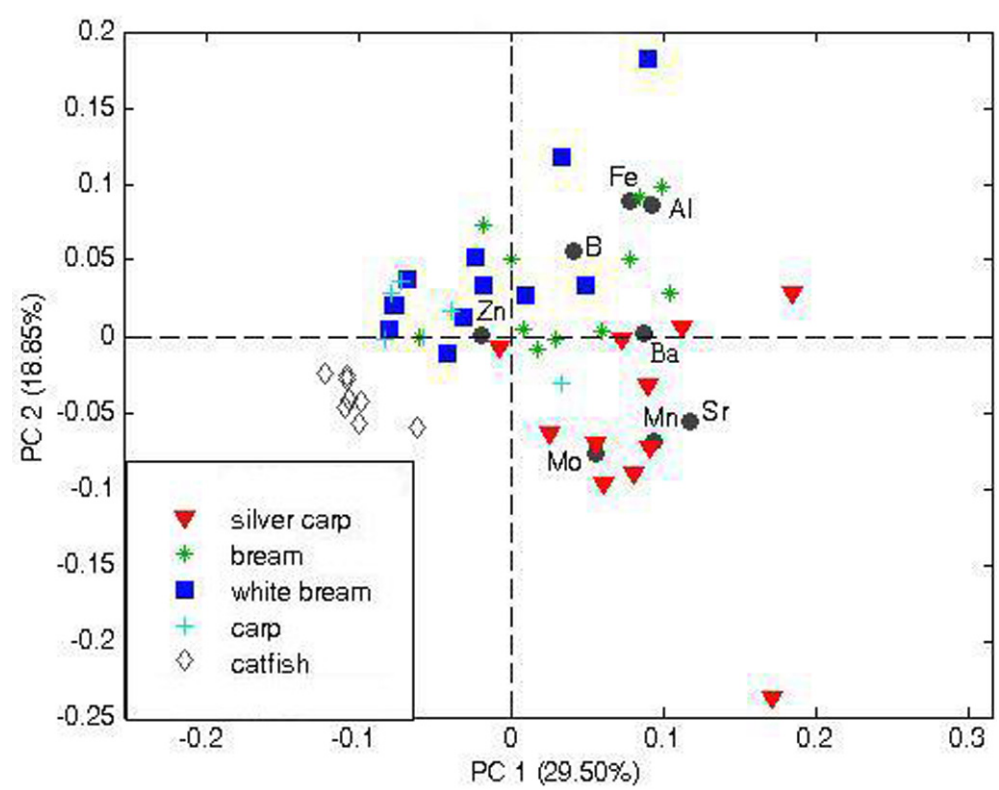

\section{Figure 1}

Principal Component Analysis applied on the elemental concentrations in gills of five studied fish species; the untreated data for elemental concentrations in gills were used as input variables.

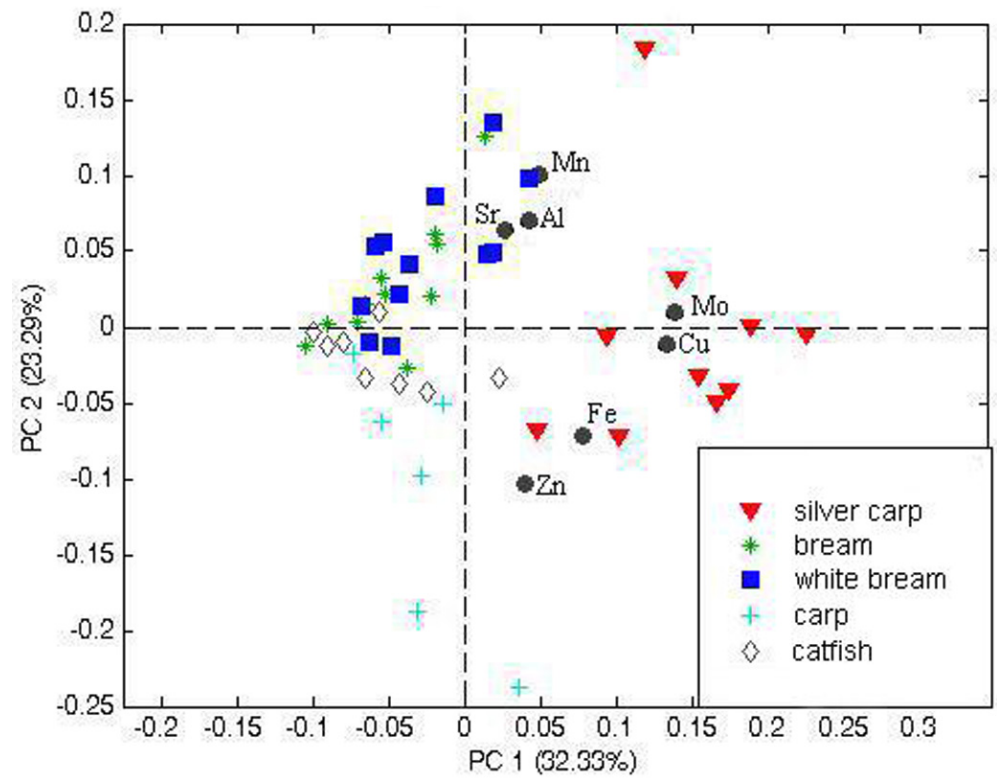

Figure 2

Principal Component Analysis applied on the elemental concentrations in liver of five studied fish species; the untreated data for elemental concentrations in liver were used as input variables.

from human diet (Has-Schön et al., 2006). Meals should be prepared without inner organs (i.e., kidney, liver and intestines; Has-Schön et al., 2008).

The accumulation patterns tend to vary among species based on their behavior and feeding habits (Agah et al. 2009) which is in accordance with the results in this study. Wels catfish had the lowest concentrations of assessed elements in gills when compared with other analyzed species, which might be explained with its different behavioral patterns. Wels catfish is predominantly a nocturnal species. During daytime, it is consistently situated in a littoral zone, where it spends extended periods of time hidden in concealed habitats (Carol et al., 2007). 
Silver carp diverged from the other four species based on elemental concentrations in liver, which could be a result of its different feeding habits (i.e., phytoplankton as its main food). Common carp, freshwater bream and white bream have relatively similar diets, which might be a reason for similar elemental accumulation patterns observed in these three species. Significantly higher $\mathrm{Zn}$ concentrations in tissues of common carp than in other four fish species might be caused by its specific physiology. This is in line with the findings of Jeng and Sun (1981) and Liao et al. (2006) that Zn concentrations in common carp digestive tract are always $>10$ times higher than in most of the animal tissues.

Our results are in accordance with the findings of other authors, namely that the highest elemental concentrations are accumulated in metabolically active tissues such as liver and gills (Rashed, 2001; Dural et al., 2006; Erdogrul and Erbilir, 2007; Kenšova et al., 2010; Poleksić et al., 2010), while muscles commonly have lower elemental concentrations (Çalta and Canpolat, 2006; Ploetz et al., 2007; Agah et al., 2009). Fish liver accumulates the highest Cu levels (Rashed, 2001), since Cu represents an inherent part of the enzymes localized in the liver (Kenšova et al., 2010). The highest Al and Sr concentrations were found in gills, which is in line with previous studies on the Danube fish (Višnjić-Jeftić et al., 2010; Jarić et al., 2011; Sunjog et al., 2012).

In the present study, there was no clear relationship observed between the fish length and the elemental accumulation. Such findings differ from previous studies on other fish species. For instance, Agah et al. (2009) observed negative length dependent relationships for almost all investigated elements in the muscles of flathead (Platycephalus sp.), greasy grouper (Epinephelus tauvina Forsskål 1775) and tigertooth croaker (Otolithes ruber Bloch \& Schneider 1801). In a study by Rashed (2001), concentrations of $\mathrm{Cu}$ in muscle and liver of Nile tilapia (Tilapia nilotica Linnaeus 1758) increased with fish age, while concentrations of Co, Fe, Mn, $\mathrm{Ni}$ and $\mathrm{Zn}$ in muscle and $\mathrm{Cr}, \mathrm{Fe}, \mathrm{Mn} \mathrm{Ni}, \mathrm{Sr}$ and $\mathrm{Zn}$ in liver slightly decreased. Such differences in results could be probably explained by differences in life histories of assessed fish species, as well as by differences in their habitats.

Numerous studies were focused on pollution in different fish species of economic importance, especially on those that represent important elements of human diet (Erdogrul and Erbilir, 2007). In that sense, our study provides valuable information, as all studied fish species also represent major object of commercial fishery in the Danube in Serbia. Moreover, since elemental concentrations in fish organs depend on the actual level of the pollution in the waterbody they inhabit, studies of elemental accumulation in fish tissues are also able to indicate the actual elemental levels in the environment (Çalta and Canpolat, 2006; Poleksić et al., 2010).

\section{ACKNOWLEDGEMENTS}

This study represents a part of activities within the Project No. 173045, funded by the Ministry of Education, Science and Technological Development of the Republic of Serbia. The authors would like to thank dr Mirjana Mihajlović for her help during the sample lyophilization, dr Miroslav Nikolić for his help during the elemental analysis, as well as two anonymous referees for providing helpful comments and suggestions.

\section{REFERENCES}

Agah H., Leermakers M., Elskens M., Fatemi S.M.R. and Baeyens W., 2009. Accumulation of trace metals in the muscle and liver tissues of five fish species from the Persian Gulf. Environ. Monit. Assess., 157, 499-514.

Alibabić V., Vahčić N. and Bajramović M., 2007. Bioaccumulation of metals in fish of Salmonidae family and the impact on fish meat quality. Environ. Monit. Assess., 131, 349-364.

Baltić M.Ž. and Teodorović V.B., 1997. Higijena mesa riba, rakova i školjki [Fish, crustaceans and mussel meat hygiene]. Faculty of Veterinary Sciences, University of Belgrade, Serbia [In Serbian]. 
Berveots L. and Blust R., 2003. Metal conentrations in water, sediment and gudgeon (Gobio gobio) from a polution gradient: relationship with fish condition factor. Environ. Pollut., 126, 9-19.

Burger J. and Gochfeld M., 2005. Heavy metals in commercial fish in New Jersey. Environ. Res., 99, 403-412.

Çalta M. and Canpolat Ö., 2006. The comparison of three cyprinid species in terms of heavy metals accumulation in some tissues. Water Environ. Res., 78, 548-551.

Carol J., Zamora L. and Garcia-Berthou E. 2007. Preliminary telemetry data on the movement patterns and habitat use of European catfish (Silurus glanis) in reservoir of the River Ebro, Spain. Ecol. Freshw. Fish 16, 450-456.

Dural M., Göksu M.Z.L., Özak A.A. and Derici B., 2006. Bioaccumulation of some heavy metals in different tissues of Dicentrarhus labrax L., 1758, Sparus aurata L., 1758 and Mugil cephalus L., 1758 from the Camlik lagoon of the eastern cost of Mediterranean (Turkey). Environ. Monit. Assess., $118,65-74$.

Erdogrul O. and Erbilir F., 2007. Heavy metal and trace elements in various fish samples from Sir Dam Lake, Kahramanmaras, Turkey. Environ. Monit. Assess., 130, 373-379.

European Commission Regulation, 2006. Setting maximum levels for certain contaminants in foodstuffs. Official Journal of the European Union, Commission Regulation No. 1881/2006/EC.

FAO, 1983. Compilation of legal limits for hazardous substances in fish and fishery products. FAO Fishery Circular, 464.

Has-Schön E., Bogut I. and Strelec I., 2006. Heavy metal profile in five fish species included in human diet, domiciled in the end flow of river Neretva (Croatia). Arch. Environ. Con. Tox., 50, 545-551.

Has-Schön E., Bogut I., Rajkovic V., Bogut S., Cacic M. and Horvatic J., 2008. Heavy metal distribution in tissues of six fish species included in human diet, inhabiting freshwaters of the Nature park "Hutovo blato" (Bosnia and Herzegovina). Arch. Environ. Con. Tox., 54, 75-83.

Jarić I. Višnjić-Jeftić Z., Cvijanović G., Gačić Z., Jovanović Lj., Skorić S. and Lenhardt M., 2011. Determination of differential heavy metal and trace element accumulation in liver, gills, intestine and muscle of sterlet (Acipenser ruthenus) from the Danube River in Serbia by ICP-OES. Microchem. J., 98, 77-81.

Jeng S.S. and Sun L.T., 1981. Effects of dietary zinc levels on zinc concentrations in tissues of common carp. J. Nutr., 111, 134-140.

Kenšova R., Čelehovska O., Doubravova J. and Svobodova Z., 2010. Concentration of metals in tissues of fish from the Vestonice Reservoir. Acta Vet. Brno, 79, 335-345.

Kirschner A.K.T., Kavka G.G., Velimirov B., Mach R.L., Sommer R. and Farnleitner A.H., 2009. Microbiological water quality along the Danube River: integrating data from two whole-river surveys and a transnational monitoring network. Water Res., 43, 3673-3684.

Lenhardt M., Marković G., Hegediš A., Maletin S., Ćirković M. and Marković Z., 2011. Non-native and translocated fish species in Serbia and their impact on the native ichthyofauna. Rev. Fish Biol. Fisher. , 21, 407-421.

Liao H-J., Chen Y.-H. and Jeng S.-S., 2006. Association of zinc with connective tissue in the digestive tract of common carp. Fish. Sci., 72, 893-902.

Ploetz D.M., Fitts B.E. and Rice T.M., 2007. Differential accumulation of heavy metals in muscle and liver of a marine fish, (king mackerel, Scomberomorus cavalla Cuvier) from the Northern Gulf of Mexico, USA. B. Environ. Contam. Tox., 78, 124-127.

Poleksić V., Lenhardt M., Jarić I., Djordjevic D., Gačić Z., Cvijanović G. and Rašković B., 2010. Liver, gills and skin histopathology and heavy metal content of the Danube sterlet (Acipenser ruthenus Linnaeus, 1758). Environ. Toxicol. Chem., 29, 515-521.

Rashed M.N., 2001. Monitoring of environmental heavy metals in fish from Nasser Lake. Environ. Int., 27, 27-33.

Smederevac-Lalić M., Regner S., Hegediš A., Kalauzi A., Višnjić-Jeftić Z., Pucar M., Cvijanović G. and Lenhardt M., 2011. Commercial fisheries on Danube in Serbia. In: V International conference "Aquaculture and Fishery" - Conference Proceedings, June 1-3, 2011, Belgrade, Serbia, 189-194.

Stanković S., 2006. The physical and chemical characteristics of Danube water quality near Kovin (Vojvodina) in Serbia. In: Proceedings of the 36th International Conference of IAD, Austrian Committee DanubeResearch / IAD, Vienna, Austria, 399-403. 
Sunjog K., Gačić Z., Kolarević S., Višnjić-Jeftić Ž., Jarić I., Knežević-Vukčević J., Vuković-Gačić B. and Lenhardt M., 2012. Heavy metal accumulation and the genotoxicity in barbel (Barbus barbus) as indicators of the Danube River pollution. Sci. World J. (Article ID 351074), 1-6.

Teodorović I., 2009. Ecotoxicological research and related legislation in Serbia. Environ. Sci. Pollut. Res., 16 (Suppl. 1), S123-S129.

Teodorović I., Djukić N., Maletin S., Miljanović B. and Jugovac N., 2000. Metal Pollution Index: proposal for freshwater monitoring based on trace metal accumulation in fish. Tiscia, 32, 55-60.

Višnjić-Jeftić Z., Jarić I., Jovanović Lj., Skorić S., Smederevac-Lalić M., Nikčević M. and Lenhardt M., 2010. Heavy metal and trace element accumulation in muscle, liver and gills of the Pontic shad (Alosa immaculata Bennet 1835) from the Danube River (Serbia). Microchem. J., 95, 341-344.

Yilmaz F., Özdemir N., Demirak A. and Tuna A.L., 2007. Heavy metal levels in two fish species Leuscius cephalus and Lepomis gibbosus. Food Chem., 100, 830-835. 